UCID- 18676

TECHNICAL EVALUATION OF THE PROPOSED

TECHNICAL SPECIFICATION CHANGE FOR THE

ARKANSAS NUCLEAR POHER STATION, UNIT 2

Richard A. Victor

August 1980

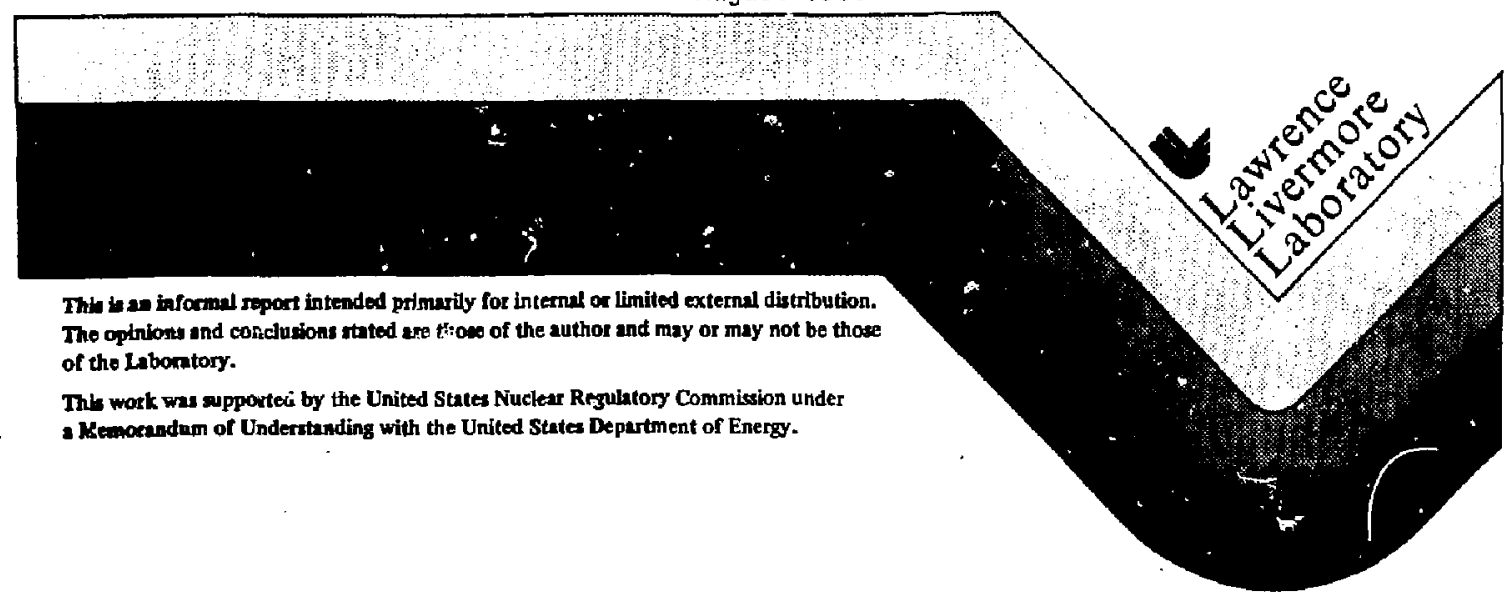

DJSTBHBUTION OF THIS DOCUMENT IS UHL MAITEO 


\section{ABSTRAC 1}

This report documents the technical evaluation of the reque $t$ for changes in the Technical Specifications for the Arkansas Nuclear Power Station, Unit 2. These changes were proposed by the licensee in a letter dated November 27, 1979. The basis for review included a report entitied "Determination of Plant System Trip Setpoints Valves." The reques ad changes to the Technical Specifications were found to be acceptable ba: id on informtion submitted by the licensee.

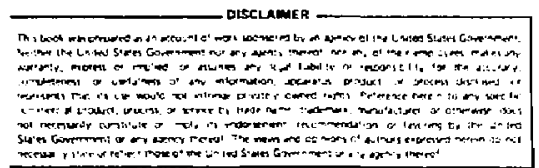

$-i j i-$ 


\section{FOREWORD}

This reoort is supplied as part of the Selected Electrical, instrumentation, aid Cortrol Systems Issues (SEICSI) Program being conducted for the U.S. Nuclear Regulatory Comission, office of Nuclear Reactor Regulations, Division of Operating Reactors, by Lawrence Livermore National Laboratory, Engineering Research Division of the Electronics Engineering Department.

The U.S. Nuclear Regulatory Commission funded the work under the authorization entitled "Electrical, Instrumentation and Control System Support," B\&R 201904031 , FIN A-0231. 
TABLE OF CONTENTS

1. INTRODUCTION . . . . . . . . . . . . . . . . . 1

2. EVALUATION OF THE PROPOSED TECHNICAL SPECIFICATION CHANGE FOR THE ARKANSAS NUCLEAR POWER STATION, UNIT 2. . . . . . . 3

2.1 Reactor Protection System/Engineered Safety Features System Setpoint Wethodology . . . . . . . . 3

2.2 Proposed Reactor Prntection System/Engineered Safety Features Actuatio, System Trip Setpoint Values. . . . . 4

3. CONCLUSIONS . . . . . . . . . . . . . . . . . 7

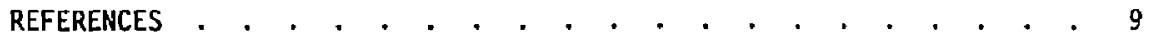

APPENDIX A . . . . . . . . . . . . . . . . A-1 
TECHNICAL EVALUATION OF THE PROPOSED TECHNICAL SPECIFICATION CHANGE FOR ARKANSAS NUCLEAR POWER STATION, UNIT 2

(Docket No. 50-368)

Richard A. Victor

Lawrence Livermore National Laboratory

\section{INTRODUCTION}

In a letter to Arkansas Power and Light, licensee for Arkansas Nuclear Power Station, Unit 2 (ANO-2), dated March 22, 1977 [Ref. 1], the NRC requested explicit information concerning each instrumentation channel trip setpoint value for the reactor protection system (RPS) and for other engineered safety features (ESFs). In Amendment 1 to the ANO-2 operating license, dated September 1, 1978 [Ref. 2], the NRC requested explicit setpoint related information for incorporation into the Technical specifications.

The licensee's response to the two NRC requests was contained in a letter dated February 28, 1979 [Ref. 3]. This letter also included a report entitled "Determination of Plant System Trip Setpoint Values" [Ref. 4], which provided the requested information and also described the setpoint methodology Combustion Engineering (CE) used to determine the setpoints at ANO-2.

A request to change the mivo-2 Technical Specifications and eliminate the dynamic allowance was submitted by the licensee in its letter dated November 27, 1979 [Ref. 5]. This request is the subject of a separate evaluation report prepares by the NRC, Plant Sysi ams Branch, DOR. 
2. EVALUATION OF THE PROPOSED TECHNICAL SPECIFICATION CHANGE

FOR THE ARKANSAS NUCLEAR POWER STATION, UNIT 2

\subsection{REACTOR PROTECTION SYSTEM/ENGINEERED SAFETY FEATURES SYSTEM SETPOINT METHODOLOGY.}

The report, "Determination of Plant System Trip Setpoint Values" [Ref. 4], details the methodology used to determine equipment setpoints, allowable values, and drift allowances for each plant protection system (PPS) function.

The equipment setpoint is the trip setpoint value that is actually set into the PPS cabinet during calibration; the allowable value is the limit on the trip setpoint at any time during normal plant operation. The allowable value is checked during a monthly channel function test.

The trip setpoint must be conservative during operation with respect to the allowable value to assure that the equipment will aperate as indicated by the safety analysis report. Drift allowance is the difference between the equipment setpoint and the allowable value, and represents the calculated equipment drift that may occur between Technical Specification surveillance tests.

Included in the Combustion Engineering (CE) report [Ref. 4] are the values for the components that are used in total equipment error calculations. The total equipment error is a combination of a random error component and a non-random component, and is calculated after the individual error components have been determined. The total equipment error represents the maximum calculated error that could occur at any time during the periodic calibration interval. 
The $\mathrm{CE}$ report also gives the margin between the analysis setpoint and the equipment setpoint. This margin is the mathematical difference between the two values. In all cases, the margin between the analysis setpoint and the equipment setpoint is larger than the total equipment error as detemined by the setpoint calculations. This margin assures that a trip actuation will occur prior to the point used in the safety analvsis.

The AN0-2 reactor protection system uses a core protection caiculation (CPC) to generate 2 of the 11 trip signals. The CPC is a digital computer system which uses a method that differs in some respects irom the method used for the other trip functions and, therefore, ensures that all equipment uncertainties are accommndated in the decision to initiate a reactor trip. The CE report [Ref. 4] describes the CPC method of uncertainty accomthodation in detail.

We have reviewed the methodalogy for the RPS/ESF instrumentation channel trip setpoint values and acknowledge that the method used for determining the total equipment error is a reasonable technique for determining the trip setpoints and allowable values for the RPS and ESF.

2.2 PROPOSEO REACTOR PROTECTION SYSTEM/ENGINEERED SAFETY FEATURES SYSTEM SETPOINT VALUES.

We have reviewed the changes to the Standard Technical Specifications for ANO-2 as submitted by Arkansas Power and Light in their February 28, 1979 letter. The values shown in Tables 2.2-1 (RPS instrumentacion trip setpoint values) and 3.3-4 (ESFAS instrumentation trip values) were compared with the values for the same functions as listed by Combustion Engineering Company, which accompanied the licensee's submittal of February 28, 1979. We find that with two exceptions these values are identical. These exceptions are as follows:

Exception 1: High pressurizer pressure reactor trip setpoint TTabTe 2.2-II.

The high pressure reactor trip setpoint [see Ref. 4] is 23 psi higher than that shown in the Technical Specifications. 
This increase is due to the elimination of the dynamic allowance. Test data has shown that the instrumentation channel response time is less than assumed in the safety analysis; therefore, the dynamic allowance factor is no longer required and has been removed, A request to change the Technical Specification to eliminate the dynamic allowance was submitted by the licensee ill its letter dated November 27, 1979 [Ref. 5].

Exception 2: Refueling Water Tank - Low (Table 3.3-4).

Table 1 in Ref. 4 gives an allowable value of $>5.111$ percent to $<6.889$ percent for the indicated level. In the Technical Specifications for ANO-2, Table 3.3-4, Item $6 \mathrm{~b}$ ("Refueling Water Tank - Low") gives an allowable value of between 5.300 percent and 6.886 percent. These values are within the range given in Table 1 of Ref. 4.

We find that the Standard Technical Specifications for ANO-2, as submitted by the licensee, are acceptable with one requested change. 
CONCLUSION

We conclude that the explicit Technical Specification trip setpoint values, the allowable values for the reactor protection system (Table 2.2-1), and the engineered safety features (Table 3.3-4) instrumentation channel trip setpoint values as submitted by the licensee for ANO-2, are acceptable. 


\section{REFERENCES}

1. NRC letter (J. F. Stolz) to Arkansas Power and Light (D. A. Reuter), dated March 22, 1977.

2. Arkansas Power and Light, "Amendment 1 to ANO-2 Operating License." dated September 1, 1978.

3. Arkansas Power and Light letter (D. A. Reuter) to NRC (J. F. Stolz), dated February 28, 1979.

4. Combustion Engineering report, "Determination of Plant System Trip Setpoint Values."

5. Arkansas Power and Light letter (W. Cavanaugh) to NRC (R. W. Reid), dated November 27, 1979. 
APPENDIX A 
Table 2.2-1. Reactor Protective Instrum : ation Trip Setpoint Limits

FUNCTLONAL UNIT

1. Nanual Reactor Trip

2. Linear Power Level - High

a. Four Reactor Coolant Pumps Operating

b. Three Reactor Coolant Pumps Operating

c. Two Reactor Coolant Pumps Operating - Same Loop

d. Two Reactor Coolant Pumps Operating - Opposite Loops

站 3. Logarithmic Power Level -
High (1)

4. Pressurizer Pressure - High

5. Pressurizer Pressure - Low

6. Contaiment Pressure - High

7. Steam Generator Pressure - Low

8. Steam Generator Level - Low

\section{TRIP SETPOINT}

Not Applicable

$\leq 123 \%$ OF RATED THERMAL POWER

$\star$

$\star$

*

$\leq 0.75 \%$ of RATED THERMAI. PUHER

$\leq 2368$ psia

$\geq 1740$ psia (2)

$<18.4$ psia

$\geq 728$ psia (3)

$\geq 46.5 .(4)$

\section{ALLOWABLE VALUES}

Not Appl icable

$\leq 123.712 \%$ Of RATED THERMAL POHER

$\star$

$\leq 0.819 \%$ of RATEL THERMAL POWER

$\leq 2376.887$ psia

$\geq 1686.75$ psia (2)

$\leq 19.07 \%$ psia

$>706.6$ psia (3)

$\geq 45.61^{\prime \prime}(4)$

\#Those values Teft blank pending NRC approval of ECCS analyses for operation with less than

fisur reactor coolant pumps operatiny. 
Table 2.2-1. Reactor Protective Instrumentation Trip Setpoint Limits (Con:inued)

\section{FUHCTIONAL UNIT}

9. Local Power Density - High

10. DNBR - LOW

11. Steam Generator Level - High

\section{TRIP SETPOINT}

$\leq 20.3 \mathrm{kw} / \mathrm{ft}(5)$

$\geq 1.3$ (5)

$\leq 93.6 \%(4)$
ALLOWABLE VALUES

$\leq 20.3 \mathrm{kw} / \mathrm{ft}(5)$

$\geq 1.3(5)$

$\leq 94.489 \%$ (4)

\section{TABLE MOTATION}

(1) Trip may be manually bypassed aboye $10^{-4} \%$ of RATED THERMAL POWER; bypass shall be automatically removed when THERMAL POWER is $\leq 10^{-4} \%$ of RATED THERMAL POWER.

(2) Value may be decreased manually, to a minimum value of 100 psia, as presurizer is reduced, provided the margin between the pressurizer pressure and this value is maintained at 2200 psi; the setpoint shall be increased automatically as pressurizer pressure is increased untit the trip setpoint is reached. Trip may be manually bypassed below 400 psia; bypass shall be automatically removed whenever pressurizer pressure is $\$ 500 \mathrm{psia}$.

(3) Value may be decreased manually as steam generator pressure is reduced, provided the margin between the steam generator pressure and this value is maintained at \& 200 psi; the setpoint shall be increased automatically as steam generator pressure is increased until the trip setpoint is reached.

(4) : of the distance between steam generator upper and lower level instrument nozzles.

(5) As stored within the Core Protection Calculator (CPC). Calculation of the trip setpoint includes measurement, calculational and processor uncertainties, and dynamic allowances. Trip may be manually bypassed DelOW $^{-4}$ of RATED THERHAL POWER; bypass shall be automatically removed when THERMAL PONER is $\geq 10^{-4}$ Of RATED THERMAL POWER. 


\section{Table 3.3-4. Engineered Safety Feature Actuation System Instrumentation Trip Values}

FUNCTIONAL UNIT

1. SAFETY INJECTION (SIAS)
a. Manual (Trip Buttons)
b. Contatnment Pressure - High
c. Pressurizer Pressure - Low

2. CONTAINMENT SPRAY (CSAS)
TRIP SETPOINT

Not Applicable

$\leq 18.4$ psta

$\geq 1740$ psía (I)

Not Applicable

$\leq 23.3 \mathrm{psia}$

b. Containment Pressure -- High-High

$$
\leq 23.3 \text { psia }
$$

\section{ALI.OWABI.E VALUES}

Not Applicable

$\leq 19.024$ psia

$\geq 1686.75$ psia (1)

3. CONTAIMMENT ISOLATION (CIAS)
Not Appl icabTe
$\leq 18.4 \mathrm{psia}$
a. Manual (Trip Buttons)
Not Applicable
$\leq 19.024 \mathrm{psia}$

4. MAIN STEAM AND FEEDHATER ISOLATION (MSIS)
a. Manual (Trip Buttons)
Not Applicable
Not Applicable
b. Steam Generator Pressure - Low
$\geq 728$ psia (2)
$>706.6$ psia (2) 
Table 3.3-4. Engineered Safety Feature Actuation System Instrumentation Trip Values (Continued)

FUNCTIONAL UNIT

5. CONTAINMENT COOLING (CCAS)
a. Manual (Trip Buttons)
b. Contaiment Pressure - High
c. Pressurizer Pressure - Low

6. RECIRCULATION (RAS)

a. Manual (Trip Buttons)

á

b. Refueling Water Tank - Low

7. LOSS OF POWER

a. 4.16 kv Emergency Bus Undervoltage (Loss of Voltage)

b. 460 volt Emergency Bus Undervol tage (Oegraded Vol tage)
TRIP VALUE

Not Applicable

$\leq 18.4$ psia

$\geq 1740$ psia (1)

Not Appl Icable

$54,400+2,370$ gallons (equivaTent to $6.0+$

$0.5 \%$ indicated leveT)

$423+2.0$ volts

with an $8.0+0.5$

second time delay

\section{ALLOWABLE VALUES}

Not Applicable

$\leq 19.024$ psia

$\geq 1686.75$ psia (1)

Not Appl icable

between 51,050 and 58,600 gallons lequivalent to between $5.300 \%$ and $6.886 \%$ indicated level)

3120 volts (4)

$423+4.0$ volts with an $8.0+0.8$ second time delay 
Table 3.3-4. Engineered Safety Feature Accuation System Instrumentation Trip Values (Continued)

\section{FUNCTIONAL UNIT}

B. EMERGEMCY FEEDWATER (EFAS)

a. Manual (Trip Buttons)

b. Steam Generator (A\&B) Level-Low

C. Steam Generator $\triangle P-H i g h(S G-A>S G-B)$

d. Steam Generator $\triangle P-H i g h(5 G-B>S G-A)$

e. Steam Generator (A\&B) Presssure - Low
TRIP VALUE

Not Appl fcable

$\geq 46.5 \%(3)$

$\leq 39$ psi

$\leq 39$ psi

$\geq 728$ psia (2)

\section{ALLDWABLE VALUES}

Not Applicable

$\geq 45.61 \%(3)$

$\leq 48.35 \mathrm{psi}$

$\leq 48.35$ psi

$\geq 706.6$ psia $(2)$

(1) Value may be decreased manually, to a minimum of $>100$ psia, as pressurizer pressure is reduced, provided the margin between the pressurizer pressure and this value is maintained at $\leq 200$ psi; the setpoint shall be increased automatically as pressurizer pressure is increased until the trip setpoint is reached. Trip may be manualiy bypassed below 400 psia; bypass shall be automatically removed whenever pressurizer pressure is $\geq 500$ psia.

(2) Value may be decreased manually as steam generator pressure is reduced, provided the margin between the steam generator pressure and this value is maintained at $<200$ psi; the setpoint shall be increased automatically as steam generator pressure is increased uñtil the trip setpoint is reached.

(3) : of the distance between steam generator upper and lower level instrument nozzles.

(4) Inverse time relay set value, not a trip value. The zero voltage trip will occur in $0.75 \pm 0.075$ seconds. 